\title{
ПЕРСПЕКТИВИ ПІДГОТОВКИ МЕДИЧНОЇ СЕСТРИ-БАКАЛАВРА З ДИСЦИПЛІНИ «АНЕСТЕЗІОЛОГІЯ ТА РЕАНІМАТОЛОГІЯ»
}

\author{
А. В. Рижковський, О. С. Грубська, Г. В. Носко \\ КЗ ТОР «Тернопільська університетська лікарня» \\ ДвНз «Тернопільський державний медичний університет \\ імені І. Я. Горбачевського МОЗ Украӥни»
}

\begin{abstract}
У статті проведено порівняљынй аналіз систем професійної підготовки медсестер України і Канади з метою удосконалення вітчизняної системи підготовки медсестер. Окреслено основні відмінності у специфіці роботи і обов'язками медсестер реанімаційтих відділень України і Канади. Вказано на гостру необхідність удосконалення професійної підготовки українських медсестер зі спеціальності «Анестезіологія і реаніматологія» і запропоновано кроки для досягненнн цієї мети.
\end{abstract}

\section{THE REGISTERED NURSES IN THE SPECIALIZATION OF ANESTHESIOLOGY AND CRITICAL CARE TRAINING PERSPECTIVES}

\author{
A. V. Ryzhkovskyi, O. S. Hrubska, H. V. Nosko \\ Municipal Institution of Ternopil Regional Counsil «Ternopil University Hospital» \\ SHEI «Ternopil State Medical University by I. Ya. Horbachevsky of MPH of Ukraine»
}

In the article was done the comparative analysis of Ukrainian and Canadian registered nurses professional training with the there aim to improve the national nurses training system. It was shown the main differences in job specificities and duties of anaesthesiology, intensive care departments nurses of Ukraine and Canada. We noted the acute necessity of Ukrainian nurses professional training development in the speciality «Anaesthesiology and Critical care» and we suggested the steps to gain this goal.

Вступ. Нині, враховуючи світовий досвід організації сестринської справи, вищі медичні навчальні заклади України працюють над тим, як змінити ідеологію медсестринства в тому сенсі, що медична сестра - це не тільки помічник лікаря, а окрема спеціальність, яка потребує особливої кваліфікації. Але, на жаль, і надалі доводиться констатувати, що функції медсестри впрактичній медицині обмежуються восновному рутинною роботою з виконання призначень лікаря: iн'єкцій, інфузійної терапії, різноманітних процедур тощо. А тому все більше стає зрозумілим, що проблема підготовки медичних сестер у нашій країні пов'язана з неузгодженістю змісту ступеневої підготовки фахівців та змістом їхньої практичної діяльності, недостатньою розробленістю нормативно-правової бази з виокремлення сестринської професії в автономну, невизначеністю статусу освітньокваліфікаційних рівнів бакалавра та магістра у галузі медсестринства. За приклад для наслідування ми взяли Канаду - країну, в якій професію медсестри вважають престижною, високооплачуваною і незалежною.

๑) А. В. Рижковський, О. С. Грубська, Г. В. Носко, 2015
Основна частина. У розвинених країнах світу медсестра - це важлива, престижна і незалежна спеціальність. У аспекті підготовки медсестринських кадрів значний науковий інтерес становить досвід провідних країн, зокрема Канади. Медична сестра в канадському суспільстві має високий соціальний статус, яскраво виражену особистісно-гуманістичну спрямованість, $\epsilon$ самостійною професією незалежного спеціаліста системи охорони здоров'я. Автономність, високе соціальне положення, можливість постійного навчання і кар'єрного росту визначають престижність і значимість сестринської справи у цій країні. Канада володіє значними педагогічними досягненнями, розвиненою багаторівневою системою професійної підготовки медичних сестер, теорія і практика якої базується на давніх багатонаціональних та історичних традиціях, що $є$ показником державної політики $[1,3]$.

Тому з метою удосконалення системи професійної підготовки кваліфікованих працівників сестринської справи в Україні для порівняння було обрано саме Канаду, де існують такі наукові ступені - бакалавр, 
магістр, доктор сестринських наук. Якщо торкнутися більш детально, то до 2005 року визнавався диплом 3 коледжу як початковий рівень вищої освіти, але вступили в дію нові правила, при яких обов'язково необхідно мати рівень бакалавра. Медсестра-бакалавр, яка працює в реанімаційному відділенні повинна мати ліцензію і спеціальний сертифікат «Critical care certificate», який дає право там працювати. Його можна отримати, якщо успішно закінчити 4-місячні повні курси у коледжі, або в університеті (у нас термін спеціалізації 2,5 місяці). Програма сертифікації в Канаді досить складна і насичена, складається з двох розділів, перший розділ розрахований на критично хворих «стабільних», а друга - на критично хворих «нестабільних». Кожний розділ складається з теоретичної і практичної частин, сертифікат видається лише тим, хто набирав 86 \% і більше правильних відповідей. Реанімаційна медсестра в Канаді проходить атестацію кожні 2 роки, у нас - кожні 5 років.

Згідно з даною ліцензією і сертифікатом, медсестрабакалавр реанімаційного відділення в Канаді відповідає за обстеження пацієнта «з ніг до голови», виконує всі призначення лікаря, самостійно знімає стандартну ЕКГ, проводить її трактування, самостійно проводить реанімаційні заходи у перші 10 хвилин клінічної смерті й синкопального стану за відсутності лікаря у відділенні - самостійно виконує дефібриляцію, кардіоверсію, встановлює зовнішні пейсмекери, тобто, за нашими стандартами, виконує функціональні обов'язки лікаря анестезіолога-реаніматолога. Але медсестри-бакалаври в Канаді також миють, перевертають, годують хворих. Зрозуміло, що за такою насиченістю і обсягом роботи, $80 \%$ робочого часу біля ліжка хворого проводять саме медсестри.

Відділення реанімації в Канаді оснащене найсучаснішою медичною технікою та устаткуванням, де все спроектовано і зроблено для зручності у роботі. Перелічимо стисло основні функціональні обов'язки і практичні навички медичної сестри реанімаційного відділення в Канаді.

Ліцензована медсестра у Канаді повинна вміти:

- проводити фізикальне і неврологічне обстеження пацієнта;

- складати план медсестринського обстеження та медсестринської допомоги;

- проводити збір криміналістичних доказів;

- здійснювати інтерпретацію лабораторних показНиків;

- проводити забір крові, забір мазків, харкотиння, сечі;
- виконувати ін'єкції, інфузійну терапію;

- виконувати катетеризацію сечового міхура як м'яким, так і твердим катетером;

- проводити оксигенотерапію;

- накладати шини/бандажі;

- встановлювати, доглядати за дренажними трубками шлунково-кишкового тракту;

- промивати шлунок;

- відсмоктувати шлунковий вміст;

- проводити моніторинг вітальних функцій пацієнта;

- доглядати за раною або стомою;

- проводити фізіотерапію патології органів грудної клітини;

- асистувати лікареві під час накладання гіпсової пов'язки та доглядати за нею;

- асистувати під час інтубації, проводити екстубацію;

- асистувати під час трахеостомії;

- асистувати під час спинномозкової пункції;

- асистувати під час торакоцентезу;

- призначати медикаментознутерапію препаратами невідкладної допомоги (аденозин, аміодарон, еуфілін, атропін, бретиліум, добутамін, допамін, дігоксин, адреналін, нітрогліцерин, метопролол, манітол, лазикс, інсулін, лідокаїн, лактулоза, діазепам, кортикостероїди, активоване вугілля та ін.) [1, 3].

Окрім вищеперерахованих, сертифікована медсестра-бакалавр реанімаційного відділення в Канаді повинна вміти:

- встановлювати пристрої для забезпечення периферичного венозного доступу;

- працювати з інфузійними насосами;

- працювати з артеріальними катетерами (нагляд, обслуговування, моніторинг показників, забір крові, видалення);

- працювати з катетером легеневої артерії (обслуговування системи, вимірювання тиску заклинювання в легеневій артерії та серцевого викиду, забір зразків крові, видалення та заміна катетера);

- зняти та інтерпретувати стандартну ЕКГ;

- здійснювати серцевий моніторинг;

- працювати з тимчасовими водіями ритму: постановка, обслуговування та моніторинг;

- проводити дефібриляцію;

- обслуговувати внутрішньоаортальну балонну помпу;

- виконувати штучну вентиляцію легень: нагляд за пацієнтом, моніторинг параметрів вентиляції;

- здійснювати моніторинг цукру капілярної крові;

- проводити аферез: доступ, нагляд за пацієнтом; 
- виконувати гемодіаліз: налаштування та відключення, обслуговування артеріовенозної фістули та артеріовенозного імплантату, встановлення канюлі, закриття доступу та забір зразків крові, видалення тромбів з катетерів;

- здійснювати автоматизований і подовжений перитонеальний діаліз: нагляд;

- проводити тривалу ниркову замісну терапію: налаштування, моніторинг, забезпечення доступу, від'єднання;

- виконувати моніторинг внутрішньочерепного тиску;

- проводити хіміотерапію: краплинне введення препаратів у сечовий міхур, болюсне введення, внутрішньом'язове введення, тривалу інфузію;

- виконувати дренаж плевральної порожнини: догляд, асистування лікареві під час введення, видалення, підготовку інструментів та обладнання;

- проводити живлення пацієнта: вводити назогастральні та орогастральні зонди;

- здійснювати моніторинг та дренування спинномозкової рідини: люмбальний дренаж - обслуговування простої дренажної системи, обслуговування та моніторинг тиску і погодинної кількості виділеної рідини;

- проводити епідуральну анестезію: болюсне введення, тривалу епідуральну інфузію і контрольовану пацієнтом анестезію - обслуговування та моніторинг; вилучення епідурального катетера;

- виконувати контрольовану пацієнтом внутрішньовенну аналгезію;

- здійснювати блокаду периферичних нервів: оцінку, моніторинг, обслуговування, видалення катетера для подовженої (тривалої) блокади стегнового нерва;

- виконувати стимуляцію периферичних нервів: налаштування, обслуговування, відключення;

- здійснювати заміну трубки після трахеостомії;

- встановлювати та обслуговувати назофарингеальні повітряпроводи;

- промивати очі;

- взяття мазка з носа та глотки;

- промивання нефростоми;

- проводити догляд за ранами: VAC-терапія - обслуговування спеціального пристрою, який закриває ранову поверхню і створює над раною розрідження, що сприяє відходженню ексудату, зменшенню бактеріального забруднення;

- проводити ендоскопію: підготовку до обстеження, асистенцію і моніторинг пацієнта, обробку апарата;
- спостерігати за розвитком плода;

- здійснювати інтранатальне вагінальне обстеження $[1,3]$.

Звісно, за технологічної насиченості, яка там існує, кваліфікація медичної сестри потребує диференційованої підготовки. Тому й потрібен у такому підрозділі бакалавр.

Практичні навички медичної сестри-бакалавра реанімаційного відділення в Україні:

- відновлення прохідності верхніх дихальних шляхів, штучне дихання «рот у рот», «рот у ніс»;

- серцево-легенева реанімація;

- підготовка дефібрилятора до роботи;

- підготовка до роботи кардіомонітора, приєднання електродів до хворого;

- технікапідшкірних, внутрішньошкірних, внутрішньом'язових, внутрішньовенних ін'єкцій;

- підготовка системи до внутрішньовенної інфузії, інфузійна терапія;

- штучна вентиляція легень ручними дихальними апаратами;

- складання набору для катетеризації магістральної вени за Сельдінгером, набору для венесекції;

- техніка введення S-подібної трубки;

- штучна вентиляція легень стаціонарними дихальними апаратами, регуляція режиму дихання;

- вимірювання центрального венозного тиску;

- переливання крові та кровозамінників;

- користування функціональним ліжком;

- підготовка до роботи та зняття ЕКГ (критичні лінії: асистолія, фібриляція);

- промивання шлунка;

- катетеризація сечового міхура м'яким катетером;

- розрахунок доз інсуліну;

- забір крові та сечі на дослідження;

- оксигенотерапія;

- складання набору, асистування під час інтубації трахеї, трахеостомії;

- догляд за тяжкохворими;

- лаваж трахеобронхіального дерева;

- проведення інгаляцій за допомогою стаціонарного інгалятора;

- годування хворих через зонд;

- постановка клізми [2].

При проведенні навіть поверхневого порівняльного аналізу між характером і тривалістю підготовки, практичними навичками медсестри-бакалавра в Канаді з тими практичними навичками медсестрибакалавра реанімаційного відділення в Україні, стає 
зрозумілим, що за обсягом, складністю і відповідальністю, відчувається наше відставання за рівнем професійної підготовки, особливо в царині технічного забезпечення підтримки вітальних функцій. У нас немає багатьох муляжів, тренажерів, блоків для відпрацювання практичних навичок і вмінь з реанімації (постановка назогастрального катетера, заміна трахеостомічної трубки та ін.), використовуваної раніше апаратури моніторингу вітальних функцій і забезпечення реанімаційного відділення для ознайомлення з цим всім студентів. Отже, у комплексному вирішенні проблеми, важливим $\epsilon$ відповідне забезпечення сучасною матеріально-технічною базою навчальних закладів і відділень реанімації, де 6 наші медсестри мали все відповідне, те що мають медсестри в Канаді для свого навчання і для роботи.

При підготовці медсестри-бакалавра з дисципліни «Анестезіологія і реаніматологія» $\epsilon$ деякі пропозиції.

На державному рівні врегулювати нормативноправові відносини для становлення медсестринства як дійсно незалежної медичної спеціальності, визначити статус освітньо-кваліфікаційних рівнів бакалавра та магістра у клінічному медсестринстві, що передбачає гнучку та критично осмислену практичну діяльність і юридичну відповідальність.

На галузевому рівні сприяти розробці і виготовленню спеціальних муляжів, тренажерів і блоків; додати до навчальної програми години для вивчення сучасних методів і методик лікування, нагляду за пацієнтом, моніторингу вітальних функцій в умовах реанімаційного відділення; ввести нову навчальну дисципліну для ВН3 I-IV рівнів акредитації «Медичне право в медсестринстві»; продовжити спеціалізацію до 4 місяцівізапочаткувати автоматизованийкомп'ютерний тестовий контроль при підвищенні кваліфікації.

\section{ЛІТЕРАТУРА}

1. Medical-surgical nursing: clinical management for positive outcomes / Joyce M. Black, Jane Hokanson Hawks // Elsevier Saunders. - 2005. - vol.1

2. Практичне медсестринство : навч. посіб. / Л. Я. Ковальчук, О. І. Яшан, С. О. Ястремська [та ін.] ; за ред. Л. Я. Ковальчука. - Тернопіль : ТДМУ, 2012. - 432 с.
В умовах коледжу, інституту і університету збільшити кількість годин-кредитів, ввівши у змістовні модулі теми, які відображали сучасні наукові досягнення матеріально-технічної бази в реанімації та анестезіології, у навчально-методичному забезпеченні, показати роль передової медичної апаратури і устаткування, їх функціональне значення та роль медсестри-бакалавра у їх практичному використанні; залучати студентів до виконання самостійних завдань (підготовка презентацій, написання науково-дослідних робіт, заняття-диспут, заняття-наукова конференція та ін.); запровадити інтердисциплінарні спеціалізації, які 6 поєднували знання, вміння і навички споріднених із сестринською справою галузей: юриспруденції та сестринської справи, педагогіки та сестринської справи, соціального піклування та сестринської справи.

Висновки. Медсестринство у Канаді - це престижна, високооплачувана, автономна ланка системи охорони здоров'я. Рівняючись на цю високорозвинену країну, можна виділити деякі найважливіші кроки для покращення підготовки вітчизняних медсестер із спеціальності «Анестезіологія та інтенсивна терапія»: 1) забезпечення студентів матеріально-технічним забезпеченням для відпрацювання практичних навичок; 2) на державному рівні врегулювати нормативноправові відносини для становлення медсестринства як дійсно незалежної медичної спеціальності; 3) додати до навчальної програми години для вивчення сучасних методів і принципів лікування, нагляду за пацієнтом, моніторингу вітальних функцій в умовах реанімаційного відділення; 4) продовжити спеціалізацію до 4 місяців; 5) ввести у змістовні модулі теми, які би відображали сучасні наукові досягнення матеріальнотехнічної бази в реанімації та анестезіології.

3. Brunner and Suddarth's textbook of medical-surgical nursing, $10^{\text {th }}$ edition / Suzanne C. O'Connell Smeltzer, Brenda G. Bare // LWW. - 2003. 